\title{
STUDI EKSPLORATIF TINGKAT KESADARAN PENGHUNI GEDUNG BERTINGKAT TERHADAP BAHAYA KEBAKARAN: STUDI KASUS DI UNIVERSITAS KRISTEN PETRA SURABAYA
}

\author{
Arief Setyawan, Endo Wijaya Kartika \\ Program Manajemen Perhotelan, Fakultas Ekonomi - Universitas Kristen Petra \\ e-mail : zuhud_arf@yahoo.co.id, endo@peter.petra.ac.id
}

\begin{abstract}
Abstrak: Bahaya kebakaran merupakan ancaman yang serius bagi penghuni gedung bertingkat. Resiko tersebut akan bertambah ketika penghuni maupun pengelola gedung kurang memiliki kesadaran tentang isu ini. Kesadaran yang baik dari para penghuni akan berguna untuk menghindari kepanikan ketika bahaya kebakaran terjadi. Kepanikan merupakan penyebab orang kolaps dan proses evakuasi sulit dilakukan. Kesadaran tentang bahaya kebakaran yang baik akan berpengaruh kepada sikap individu dan seterusnya akan berpengaruh kepada perilaku. Penghuni gedung bertingkat yang memiliki kesadaran baik akan berperilaku positif dengan tidak panic menghadapi kebakaran. Mereka akan berusaha untuk mengantisipasi dan memproteksi setiap ancaman kebakaran.
\end{abstract}

Kata kunci: Bahaya kebakaran, kesadaran tentang bahaya kebakaran, gedung bertingkat

\begin{abstract}
Fire become such a serious risk for anyone staying in a high rise building. The risk tend to be double should either the developer and the users neglect on the issues. Fire which happened to a high rise building will be badly harmful compared to the other locations. The good awareness on the Fire danger of anyone occupying the building will be very useful for avoiding panic which some expert said as the main factor of either making people collapse or evacuation process goes very difficult to do. Good awareness will reflect to attitudes and later it will stimulate the behavior. High rise building occupant which has good awareness will behave theirselves at least being of not panic once the real fire happened, furthermore they will always find their way to protect and anticipate the fires.
\end{abstract}

Keywords: Fire, fire awareness, high rise building

Bahaya kebakaran telah menjadi ancaman yang serius bagi penghuni maupun pemakai gedung gedung bertingkat terutama di daerah yang menjadi sentra layanan dan bisnis. Ancaman dan resiko yang diakibatkan oleh bahaya kebakaran ini akan semakin besar ketika pemilik dan pemakai dari bangunan tersebut tidak memiliki kesadaran yang tinggi untuk mengantisipasi dan menangkal bahaya yang mungkin timbul dari ancaman ini. Sebuah data resmi dari United States National Fire Protection Association (US NFPA) yang diterbitkan tahun 2008 menjelaskan tentang kerugian yang diakibatkan dari bencana kebakaran ini. Dari rata rata 350.000 kali bencana kebakaran di daerah perumahan dan perkantoran yang terjadi dalam setahun, 15.300 kali merupakan kejadian kebakaran di gedung-gedung bertingkat di seluruh Amerika serikat dengan rata rata 60 orang meninggal, 930 luka-luka dan 52 juta dollar kerugian hangus terbakar mengikuti bencana kebakaran di gedung gedung bertingkat tersebut.

Hasil temuan menyatakan bahwa kebakaran di gedung bertingkat lebih mematikan dan merugikan dari lokasi-lokasi lain dimana bencana kebakaran terjadi. Ditambah lagi penanganan kebakaran di lokasi gedung bertingkat lebih menyulitkan dan beresiko tinggi. Sebuah data dikutip dari National Academy of Sciences US (1986) mencatat bahwa 50\% sampai 80\% kematian karena kebakaran disebabkan oleh racun asap yang keluar dari bencana kebakaran. Data lain dari Jurnal Suprapto (2008) yang didapatkan dari NFPA (USA) menjelaskan bahwa asap merupakan pembunuh terbesar dalam kejadian kebakaran Sebanyak 72\% korban kebakaran diakibatkan oleh asap. Dengan kecepatan asap berkisar antara 1.0 - 1.4 $\mathrm{m} /$ detik, maka dengan mudah asap bisa melampaui kecepatan jalan anak-anak, wanita hamil dan orangorang memiliki keterbatasan (diffabled) saat dilakukan evakuasi. Fakta yang sama juga terjadi di Indonesia, dimana kejadian kebakaran di gedung bertingkat juga sering terjadi. Yang paling akhir adalah kebakaran karaoke di Medan yang dimuat di Wacana Suara Merdeka terbit 5 Januari 2010 dimana menelan 20 orang korban tewas meskipun terjadi di dalam lokasi sebuah gedung berlantai empat saja. Diketahui 
sebagian besar korban tewas karena menghirup asap hasil kebakaran ketika mereka kesulitan mencari jalan keluar dari lokasi kebakaran di lantai tiga gedung tersebut.

Tak terkecuali dengan bangunan kampus perguruan tinggi, setidaknya ada data tentang kebakaran yang terjadi di dua kampus di Jakarta. Yang pertama di kampus STIE Perbanas di daerah Kuningan yang meskipun tidak ada korban jiwa telah menghanguskan lantai tujuh. Diketahui ruang arsip, ruang rapat dan ruang penelitian hangus terbakar. Tahun 2001, Ruang seminar dan penelitian di gedung Dekanat Fakultas Tehnik kampus Universitas Indonesia Depok berantakan dikarenakan kebakaran yang terjadi. Meskipun tidak ada korban jiwa tetapi kejadian tersebut telah mengganggu operasionalisasi kampus. Diketahui keduanya disebabkan oleh terjadinya arus pendek pada instalasi listriknya. (MAKARA, TEKNOLOGI :2008)

Dari temuan dan fakta di atas, penulis tertarik melakukan sebuah survei eksploratif mengenai tingkat kesadaran akan bahaya kebakaran yang setiap saat bisa terjadi di kampus Universitas Kristen Petra Surabaya. Hasil penelitian diharapkan dapat member gambaran bagaimana setiap penghuni kampus bisa mengantisipasi dan bereaksi jika bahaya itu datang.

\section{TEORI PENUNJANG}

\section{Kesadaran Terhadap Bahaya Kebakaran}

Mengutip definisi dari Wikipedia, kesadaran (awareness) merupakan unsur dalam manusia dalam memahami realitas dan bagaimana cara bertindak atau menyikapi suatu realitas. Refleksi merupakan bentuk dari pengungkapan kesadaran, dimana ia dapat memberikan atau bertahan dalam situasi dan kondis tertentu dalam lingkungan. Sebuah bagan yang dibuat Fishbein (1967) yang menggambarkan keterkaitan antara kesadaran terhadap bahaya kebakaran (fire awareness) dengan perubahan sikap dari individu. Keyakinan akan bahaya kebakaran menimbulkan munculnya kesadaran yang mengarahkan seseorang untuk bersikap, dimana dia akan memiliki kecenderungan untuk berpikir proaktif tentang bagaimana untuk menghindari, mengantisipasi bahaya kebakaran tersebut. Dengan intensitas yang berkelanjutan, sikap sikap proaktif ini akan mengarahkan kepada perubahan perilaku yang responsif terhadap bahaya kebakaran seperti bagaimana mengantisipasi dan meminimalisir resiko dari bahaya kebakaran apabila harus terjadi.

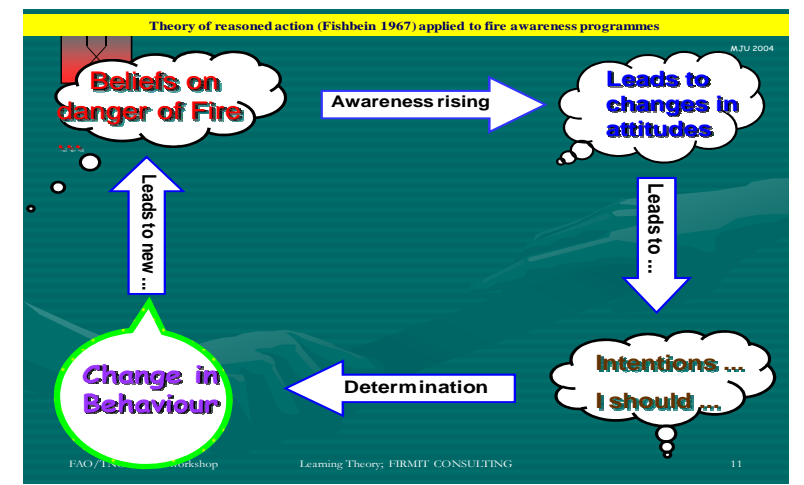

Sumber: FAO/CBFiM workshop programme by Firmit Consulting (2007)

Gambar 1. Teori yang dikemukakan oleh Fishbein mengenai alasan untuk beraksi (Reasoned Action) untuk menumbuhkan kesadaran tentang Kebakaran.

Teori lain tentang pentingnya program pelatihan manajemen bahaya kebakaran dinukil dari presentasi Applied Course by $\mathrm{MJu}$ from training of instructors/teachers in more than 40 countries between 1965-2007. Pelatihan kebakaran yang terencana dengan baik dan berkelanjutan akan mengarahkan pesertanya kepada perubahan sikap dengan ditandai dengan pendewasaan emosi dan respon kognitif berupa penguasaan pengetahuan tentang bahaya api yang menggerakkan seseorang untuk merubah perilakunya sehingga selalu responsif terhadap bahaya yang mungkin timbul dari sebuah kebakaran. Perubahan perilaku merupakan faktor yang penting yang bisa menggerakkan seseorang untuk selalu siaga dengan berbagai ancaman kebakaran.

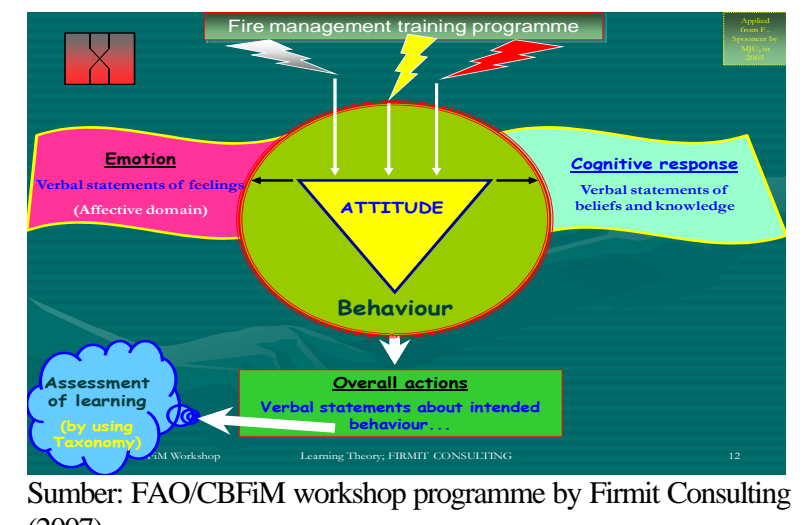
(2007)

Gambar 2. Teori tentang Keterkaitan anatara Program training kebakaran dengan Perubahan Perilaku terhadap bahaya kebakaran. 


\section{Bahaya Kebakaran}

Kebakaran merupakan kejadian yang muncul dari adanya api yang tidak terkontrol. Teori Segitiga Api menjelaskan tentang munculnya api, yakni berupa reaksi oksidasi cepat yang timbul apabila muncul tiga faktor pencipta api secara bersamaan, yakni Bahan yang mudah terbakar, adanya Oksigen dan adanya Panas yang sampai pada titik penyalaannya.

Artikel Sunarno dalam Anjungnusa edisi XIV (2009) menjelaskan tentang hasil sebuah pembakaran dan bahayanya terhadap keselamatan jiwa manusia. Ada 5 produk hasil dari sebuah pembakaran yakni gas hasil pembakaran,nyala api (flame), panas, asap, dan pengurangan kadar oksigen. Kelima produk pembakaran ini akan sangat berpengaruh secara fisiologis terhadap kehidupan. Namun yang paling penting adalah pengaruh terbakar dan keracunan. Penyelidikan terhadap kebakaran menunjukkan bahwa selama terjadi kebakaran dihasilkan sejumlah gas beracun, dengan tingkat toksisitas yang rendah sampai yang mematikan, antara lain carbon monoksida, carbondioksida, hidrogensulfida, sulfurdioksida, ammonia, hidrogensianida, nitrogendioksida, acrylicaldehid, dan phosgene.Terbakarnya bahan bakar dengan kandungan oksigen yang cukup, biasanya menghasilkan sesuatu yang terang yang disebut “nyala api”(flame). Dengan hembusan angin yang kencang nyala api ini dapat menyebar jauh dari sumber api itu sendiri, dan mengakibatkan kebakaran di tempat yang lain dan apabila mengenai korban akan mengakibatkan luka bakar. Kebakaran yang terjadi di gedung perkantoran, rumah atau hotel, panas yang dihasilkan akan berpengaruh sekali terhadap kesehatan, dari yang ringan sampai meninggal dunia.

Terperangkap pada suatu ruang dengan panas tinggi akan menyebabkan tubuh mengalami dehidrasi hebat. Panas juga akan mengakibatkan meningkatnya denyut jantung secara drastis. Apabila pengaruh panas tersebut sudah tidak dapat diatasi lagi, maka si korban akan meninggal dunia. Asap, yang merupakan partikel-partikel kecil dalam ukuran mikron juga dapat sangat berbahaya bagi kesehatan manusia. Penyebaran asap yang lebih cepat dari sebaran kebakaran (fire spread) akan dapat berfungsi sebagai peringatan dini. Namun dilain pihak asap akan dapat menimbulkan kepanikan,stress dan kehilangan kontrol, sehingga menimbulkan kerugian sebelum kebakaran benarbenar menyebar.

Partikel asap dalam jumlah yang cukup banyak, akan mengakibatkan iritasi di mata dan terpapar asap untuk jangka waktu yang lama mungkin akan mempengaruhi pernapasan. Munculnya gas beracun dan asap pada suatu ruangan yang terbakar akan menimbulkan kehilangan orientasi. Jika turun lebih rendah lagi ke angka 14-10 persen, korban mulai kehilangan kepercayaan diri dan menjadi sangat capai.Pada konsentrasi 10 sampai 6 persen, korban akan pingsan tak sadarkan diri.

Dikenal ada 4 macam kelas api kebakaran seperti pada Tabel 1.

Alat dan Instalasi yang dipakai untuk meng-

Tabel 1. Klasifikasi Api menurut Kelas dan Cara Penanganannya

\begin{tabular}{|c|c|c|c|}
\hline \multicolumn{2}{|c|}{ KELAS API PENJELASAN } & CONTOH & JENIS PEMADAM \\
\hline $\mathrm{A}$ & $\begin{array}{l}\text { Kebakaran yang } \\
\text { disebabkan oleh benda- } \\
\text { benda padat. }\end{array}$ & $\begin{array}{l}\text { kertas, kayu, plastik, karet, } \\
\text { busa dan lain-lainnya. }\end{array}$ & $\begin{array}{l}\text { Air, pasir, karung goni yang dibasahi, dan Alat } \\
\text { Pemadam Kebakaran (APAR) atau racun api tepung } \\
\text { kimia kering. }\end{array}$ \\
\hline B & $\begin{array}{l}\text { Kebakaran yang } \\
\text { disebabkan oleh benda- } \\
\text { benda mudah terbakar } \\
\text { berupa cairan. }\end{array}$ & $\begin{array}{l}\text { bensin, solar, minyak } \\
\text { tanah, spirtus, alkohol dan } \\
\text { lain-lainnya. }\end{array}$ & $\begin{array}{l}\text { Pasir dan Alat Pemadam Kebakaran (APAR) atau } \\
\text { racun api tepung kimia kering. Dilarang memakai air } \\
\text { untuk jenis ini karena berat jenis air lebih berat dari } \\
\text { pada berat jenis bahan di atas sehingga bila kita } \\
\text { menggunakan air maka kebakaran akan melebar } \\
\text { kemana-mana }\end{array}$ \\
\hline $\mathrm{C}$ & $\begin{array}{l}\text { Kebakaran yang } \\
\text { disebabkan oleh gas }\end{array}$ & $\begin{array}{l}\text { Acetylene,gas alam } \\
\text { butane,propane,metane }\end{array}$ & Matikan saluran gas, APAR, Carbon Dioxide. \\
\hline $\mathrm{D}$ & $\begin{array}{l}\text { Kebakaran yang } \\
\text { disebabkan oleh logam }\end{array}$ & $\begin{array}{l}\text { Aluminium,magnesium, } \\
\text { sodium, potassium, } \\
\text { lithium }\end{array}$ & $\begin{array}{l}\text { Metal fire powder (D Powder, } \\
\text { dry sand, dry road or } \\
\text { animal salt, dry cement and } \\
\text { cast iron filings }\end{array}$ \\
\hline $\mathrm{F}$ & $\begin{array}{l}\text { Kebakaran minyak/lemak } \\
\text { pada makanan dan alat } \\
\text { pemroses makanannya }\end{array}$ & $\begin{array}{l}\text { Minyak goreng dan lemak } \\
\text { makanan }\end{array}$ & Unsole (cairan pemadam kebakaran), Pan Lids \\
\hline
\end{tabular}

Sumber: Hoyer Brandschuts GmBh 
antisipasi bahaya kebakaran

Gedung bertingkat memerlukan beberapa peralatan sebagai media pengantisipasi bahaya kebakaran. Berikut beberapa peralatan standar yang biasa dipakai di gedung gedung bertingkat.

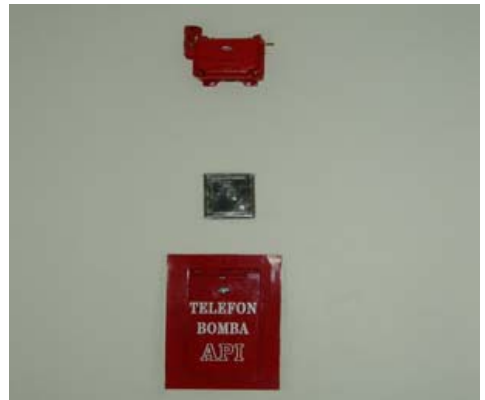

Gambar 3. Kotak hydrant

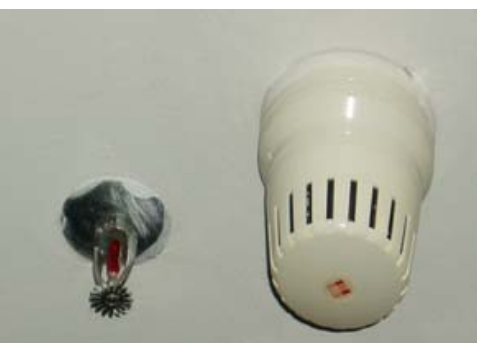

Gambar 4. Sprinkler \& Smoke detector

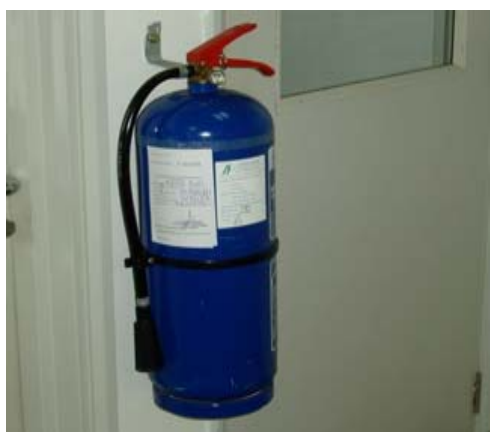

Gambar 5. APAR (alat pemadam api ringan)

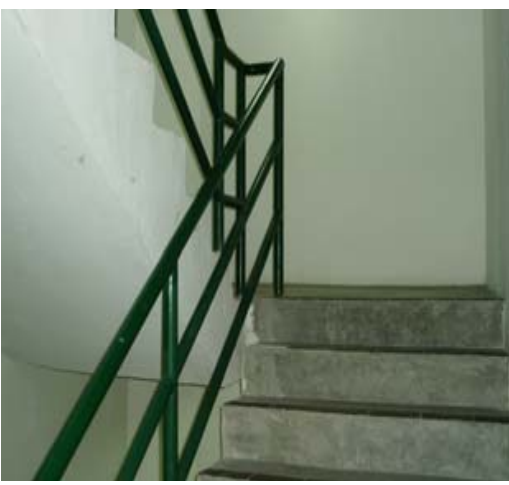

Gambar 6. Tangga Darurat

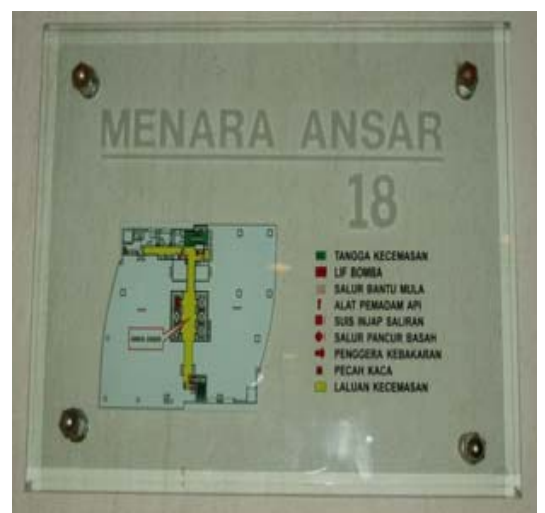

Gambar 7. Peta Evakuasi

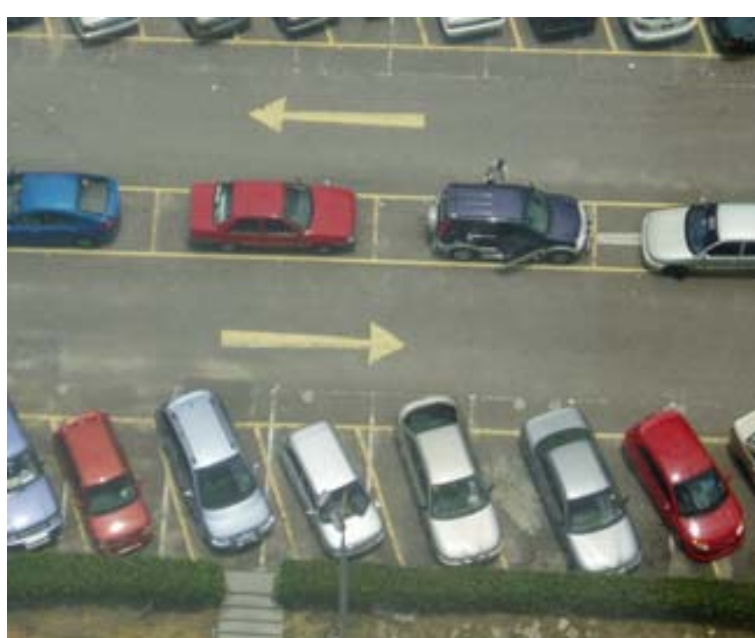

Gambar 8. Assemby Mtg Point (tempat berkumpul saat evakuasi)

Sumber Gambar 3-8: Tesis Nawal Khuzairi, UNIVERSITI TEKNOLOGI MALAYSIA (2007)

Hydrant Box: Alat pemadam kebakaran ketika api sudah membesar, terdiri dari selang yang terhubung dengan pipa hydrant (saluran air bertekanan tinggi), Host (moncong selang berfungsi sebagai pengontrol arah air). Hydrant box difungsikan ketika APAR tidak lagi bisa mengatasi api.

Sprinkler: Alat pendeteksi panas ruangan, terdiri dari tabung kecil berisi cairan yang punya titik jenuh panas. Alat ini terhubung dengan selang kecil dan sumber air. Tabung akan pecah ketika temperature ruangan menyebabkan cairan dalam tabung sampai titik jenuh panasnya. Saat telah pecah, selang terbuka dan memancarkan airnya.

Smoke Detector: Alat pendeteksi asap, bekerja dan mengeluarkan isyarat bunyi saat mendeteksi adanya asap di ruangan dimana alat ini diinstalasi. Asap adalah ciri adanya api. 
APAR: Singkatan dari Alat Pemadam Kebakaran Ringan, sebuah alat pemadam portable untuk pemadaman api yang masih berskala kecil.

Tangga Darurat: Tangga yang disiapkan untuk sarana evakuasi kebakaran, diletakkan di tempat yang tahan api dan diujung-ujung jalanya dilengkapi dengan pintu yang tahan api. Tangga darurat terhubung dengan assembly meeting point (tempat berkumpul).

Peta Evakuasi: Sebuah denah yang menjelaskan ke arah mana para penghuni harus meninggalkan tempat saat terjadi kebakaran dan proses evakuasi berlangsung.

Assembly Meeting Point: Tempat akhir / tujuan dari proses evakuasi kebakaran, merupakan sebuah tanah lapang yang terpisah dari bangunan dan disiapkan untuk mengumpulkan penghuni bangunan. Di tempat ini biasanya akan didata siapa saja penghuni yang sudah dan belum meninggalkan gedung saat terjadi kebakaran.

Faktor-Faktor Yang Mempengaruhi sikap dan respon Penghuni Bangunan terhadap Bahaya Kebakaran

Respon perilaku manusia terhadap kebakaran ikut menentukan keberhasilan proses pemadaman kebakaran maupun keselamatan manusia itu sendiri. Respon ini sangat bervariasi. Respon yang tepat dan dengan tenang dilaksanakan akan mempercepa proses pemadaman. Sebaliknya, respon yang negatif, seperti misalnya panik, akan menghasilkan upaya yang justru kontraproduktif. Proux (2001) dalam tesis yang ditulis oleh Khuzairi (2007) menjelaskan tentang sikap individu ketika menghadapi sebuah bahaya kebakaran. Ada 3 elemen utama yang mendasari seseorang dalam bersikap ketika menghadapi bahaya kebakaran, yakni:

- Ciri-ciri penghuni bangunan

- Ciri-ciri bangunan

- Ciri-ciri api kebakaran

Ciri penghuni bangunan berpengaruh kepada sikap yang diambil. Dicontohkan jenis kelamin, berpengalaman atau tidak, apakah penghuni adalah pemilik/pekerja/pengunjung, penghuni mudah terpengaruh atau percaya diri adalah sangat menentukan sikap yang diambil para penghuni tersebut ketika terjadi kebakaran. Penghuni perempuan lebih memilih untuk lari secepatnya daripada laki-laki yang akan berusaha menghadapi api terlebih dahulu.Sementara itu, ciri bangunan seperti gedung yang berfungsi sebagai kantor atau rumah sakit akan membedakan sikap para penghuninya dalam mengambil sikap untuk menghadapi kebakaran.Penghuni kantor relatif akan lebih bersikap tanggap daripada mereka yang tinggal di rumah sakit. Demikian juga cirri-ciri api kebakaran menentukan sikap yakni bau barang terbakar belum membuat orang lari akan tetapi api yang besar disertai asap membuat orang bersikap untuk segera lari meninggalkan tempat.

Pendapat Wood (1972) dalam tesis yang ditulis oleh Khuzairi (2007) menjelaskan tentang keputusan seseorang dalam meninggalkan tempat ketika terjadi kebakaran adalah berdasarkan faktor faktor berikut:

1. Jenis kelamin, semisal wanita yang lebih dulu meninggalkan tempat daripada pria.

2. Pengetahuan tentang bahaya \& resiko kebakaran, yakni orang yang telah punya pengetahuan tentang kebakaran akan tidak terburu buru keluar dari

Tabel 2. Tabel tentang 3 elemen utama yang mendasari seseorang dalam bersikap ketika menghadapi bahaya kebakaran.

\begin{tabular}{|c|c|c|}
\hline Ciri-ciri penghuni Bangunan & Ciri- ciri Bangunan & Ciri ciri Kebakaran \\
\hline - $\quad$ Profil (Umur, jenis kelamin, keterbatasan fisik) - & $\begin{array}{l}\text { - Arsitektur/Reka bentuk (Jumlah lantai, } \\
\text { kompleksitas ruangan, tangga darurat, pintu } \\
\text { keluar) }\end{array}$ & - Bau Barang terbakar \\
\hline Pengalaman \& pengetahuan & $\begin{array}{l}\text { - Sistem keselamatan bangunan (fasilitas fire } \\
\text { paging dan pendeteksi kebakaran) }\end{array}$ & Munculnya Asap \\
\hline $\begin{array}{l}\text { Situasi saat kebakaran terjadi ( sedang sendiri, } \\
\text { bersama orang lain, dalam pengaruh } \\
\text { obat/alkohol) }\end{array}$ & $\begin{array}{l}\text { - Aktivitas dalam bangunan( ruang kantor, } \\
\text { tempat tidur, ruang makan, ruang santai) }\end{array}$ & - Munculnya Api \\
\hline $\begin{array}{l}\text { Sifat (personality) yakni mudah terpengaruh, - } \\
\text { percaya diri, ingin tahu. }\end{array}$ & $\begin{array}{l}\text { - Jenis bangunan (tempat tinggal,rumah sakit, } \\
\text { hotel,asrama, kampus universitas) }\end{array}$ & Bunyi barang pecah \\
\hline $\begin{array}{l}\text { - Peran saat kebakaran terjadi (pemilik, pekerja, } \\
\text { penguniung)penruhg }\end{array}$ & & - Jatuhnya barang/kaca \\
\hline
\end{tabular}

Sumber : Kuzairi (2007) 
ruangan karena tahu betul resiko yang akan terjadi. Mereka akan meninggalkan tempat ketika usaha untuk memadamkan api gagal.

3. Ketebalan asap, yakni semakin pekat asap sebuah kebakaran semakin menentukan sikap penghun sebuah gedung untuk segera mengosongkan ruangan.

4. Pengalaman menghadapi kebakaran, yakni seseorang semakin berusaha bertahan untuk tidak mengosongkan ruangan dan berusaha untuk memadamkan api ketika dia berada di sebuah ruangan dimana kebakaran terjadi.

5. Latihan menghadapi situasi kebakaran, yani orang dengan integritas yang tinggi akan bertahan karena telah terlatih dengan latihan-latihan mengadapi kebakaran.

\section{METODE PENELITIAN}

Populasi dalam penelitian ini adalah para penghuni bangunan bertingkat yang ada di Universitas Kristen Petra. Responden dipilih dengan teknik convenience sampling di unit gedung bertingkat yang dimiliki oleh UK Petra yakni Gedung A, W dan gedung P. Telah diambil 100 orang responden dari ketiga bangunan bertingkat yang dimiliki oleh petra yakni dengan cara mendatangangi para reponden yang sedang beraktifitas di masing-masing gedung tersebut. Survei dilakukan selama 7 hari kuliah antara tanggal 1 sampai 10 mei 2010. Dari 100 orang responden yang telah mengisi kuesioner, didapati 6 kuesioner yang tidak valid.

Universitas Kristen Petra memiliki kampus terpadu dan berlokasi di satu tempat di Daerah Siwalankerto. Ada 10 Unit gedung yang terpisah, Yakni, gedung A,B,C,D,E, I,J,P,T,W. Empat unit gedung dipilih menjadi lokasi pengambilan sampe survey, yakni gedung P \& W yang berlantai 10 serta gedung $\mathrm{A}$ dan $\mathrm{T}$ yang berlantai empat atu lebih. Semua gedung yang dimiliki oleh Universitas Kristen Petra telah didesain dengan perencanaan untuk secara maksimal bisa mengantisipasi ancaman kebakaran. Fasilitas seperti tangga darurat, fire exit, assembly meeting area, dan fasilitas pendukung lain telah didesain dengan baik. Alat dan instalasi pemadan kebakaran telah disiapkan di tiap lantai di semu bangunan yang ada di UK Petra. Kesemua fasilita tersebut akan berfungsi dengan maksimal ketika kesadaran para penghuninya sesuai seperti yang diharapkan.

Dari studi literatur di atas, penulis merumuskan definisi operasional dari variabel kesadaran adalah sebagai kecakapan untuk memahami realitas dan bagaimana cara bertindak atau menyikapi suatu realitas. Adapun untuk mengukur variabel kesadaran penghuni gedung bertingkat digunakan beberapa indikator penelitian berikut:

1. Pemahaman responden akan bahaya yang ditimbulkan oleh bencana kebakaran.

2. Pemahaman para responden untuk menggunakan alat pemadan kebakaran ringan.

3. Pemahaman para responden untuk mencari pintu jalan keluar yang direkomendasikan ketika terjadi kebakaran.

4. Pemahaman responden terhadap isyarat pemberitahuan tentang evakuasi korban kebakaran( evacuation paging) dan respon mereka terhadap pemberitahuan tersebut.

5. Pemahaman responden terhadap istilah assembly meeting point (lapangan tempat berkumpul ketika terjadi evakuasi kebakaran).

6. Pemahaman responden dengan betapa berbahayanya asap yang ditimbulkan oleh bencana kebakaran.

7. Pemahaman responden tentang bahaya dari penggunaan lift ketika terjadi kebakaran.

Selain mengukur tingkat kesadaran penghun gedung bertingkat terhadap bahaya kebakaran, penulis juga meneliti 2 hal lain diluar ketujuh indikator di atas:

1. Keterkaitan antara informasi tentang bahaya kebakaran serta latihan kebakaran dengan pemahaman para responden akan bahaya kebakaran.

2. Menemukan media yang paling direkomendasikan oleh para responden untuk meningkatkan kesadaran tentang bahaya kebakaran ini.

\section{HASIL DAN PEMBAHASAN}

Dari hasil survey yang dilakukan, penulis mendapatkan temuan berikut:

1. Pemahaman responden akan bahaya yang ditimbulkan oleh bencana kebakaran.

Survey mendapatkan temuan bahawa 99\% responden pernah mendengar berita tentang korban atau kerugian yang diakibatkan oleh kebakaran. Hal ini menunjukkan bahwa hampir semua responden menyadari akan bahaya dan resiko dari sebuah kebakaran.

2. Pemahaman para responden untuk menggunakan alat pemadan kebakaran ringan.

Tindakan pertama ketika mengetahui api sangat penting untuk meminimalkan resiko kerugian yang besar dari sebuah bencana kebakaran. Respon yang cepat untuk memadamkan api dengan peralatan yang ada, akan sangat membantu 
untuk mencegah menjalarnya api menjadi besar. Peralatan APAR (alat pemadam api ringan) telah disediakan di hampir semua lantai gedung bertingkat yang ada di UK Petra. Hasil survey menunjukkan bahwa 60\% responden tidak mengerti apa itu APAR. Sebaliknya 40\% responden yang paham, seperempatnya tidak tahu dimana letak pemadam ini serta setengahnya saja yang mengerti pengoperasian alat tersebut.

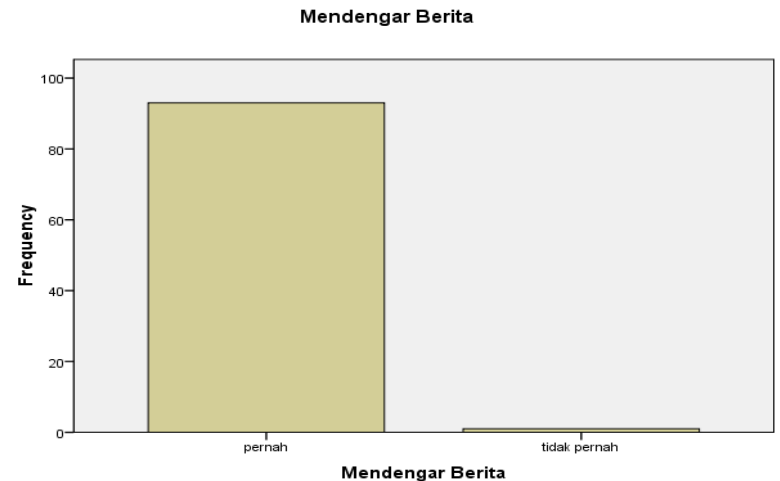

Gambar 9. Tabel tentang Pengalaman Responden mendengar berita tentang resiko dan kerugian akibat kebakaran.

Apakah anda paham dengan APAR
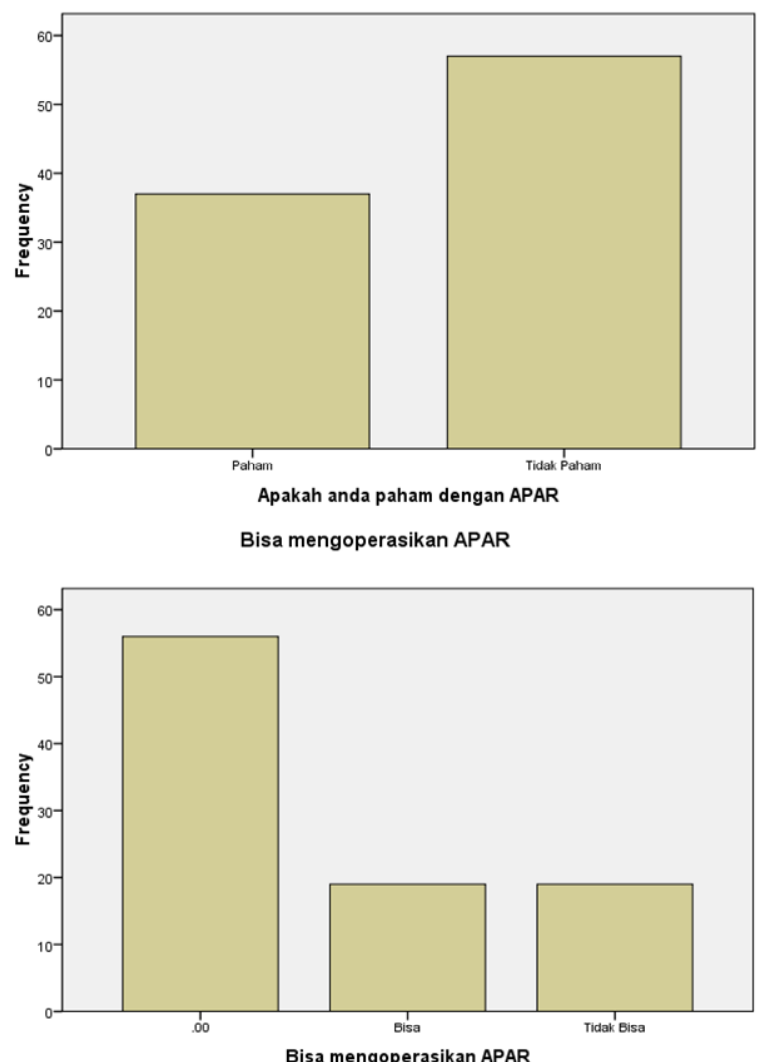

Gambar 10. Pengetahuan responden tentang APAR dan pengoperasiannya.
3. Pemahaman para responden untuk mencari pintu jalan keluar yang direkomendasikan ketika terjadi kebakaran.

Fire Exit adalah bagian dari infrastruktur bangunan bertingkat yang disiapkan sebagai jalan untuk melarikan diri dari bahaya api maupun asapnya.Instalasinya terdiri dari penunjukpenunjuk arah (exit signs) beserta tangga darura yang sudah disiapkan mulai dari lantai tertinggi sampai ke lantai dasarnya. Pintu-pintu yang ada di tangga darurat didesain sangat rapat dan kuat untuk mengantisipasi masuknya asap dan api. Hasil survei menunjukkan $69 \%$ saja yang mengetahui lokasi fire exit, 31\% atau sepertiganya menjawab tidak tahu.

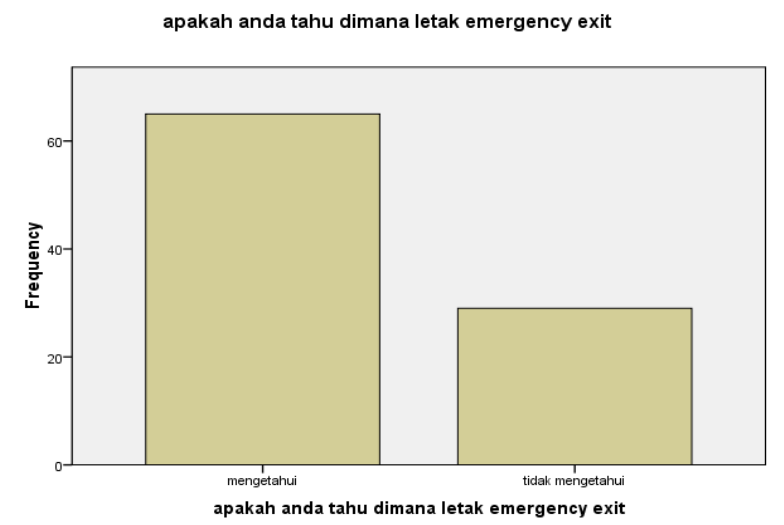

Gambar 11. Pengetahuan Responden Tentang Emergency Exit

4. Pemahaman responden terhadap isyarat pemberitahuan tentang evakuasi korban kebakaran (evacuation paging) dan respon mereka terhadap pemberitahuan tersebut.

Evakuasi kebakaran adalah tingkatan akhir dari penyelamatan bencana kebakaran dimana semua orang yang ada di dalam bangunan harus meninggalkan tenpat. Informasinya biasanya diperdengarkan melalui sebuah sistem alarm dan paging (mikrofon). Jika terjadi evakuasi, alarm biasanya akan berbunyi terus menerus dan pemberitahuan evakuasi lewat mikrofon akan diperdengarkan. Hasil survey menunjukkan 23\% saja dari responden pernah mendengar dan sisanya tidak punya pengalaman tentang hal ini.

5. Pemahaman responden terhadap istilah assembly meeting point (lapangan tempat berkumpul ketika terjadi evakuasi kebakaran).

Assembly meeting point atau tempat bekumpul ketika terjadi proses evakuasi merupakan area yang didesain sebagai tujuan akhir ketika para penghuni gedung bertingkat meninggalkan 
bangunan. Area ini biasanya berupa tanah lapang yang terbebas dengan induk bangunan bertingkat. Di tempat ini biasanya dilakukan pendataan para penghuni gedung, sehingga diketahui siapa saja yang masih berada di dalam bangunan. Hasil survei menunjukkan 43\% saja dari responden yang paham dengan istilah ini dan yang lebih mengherankan lagi adalah hanya 33\% saja responden yang tahu lokasi assembly meeting point.

Pernahkah mendengar pemberitahuan tentang evakuasi

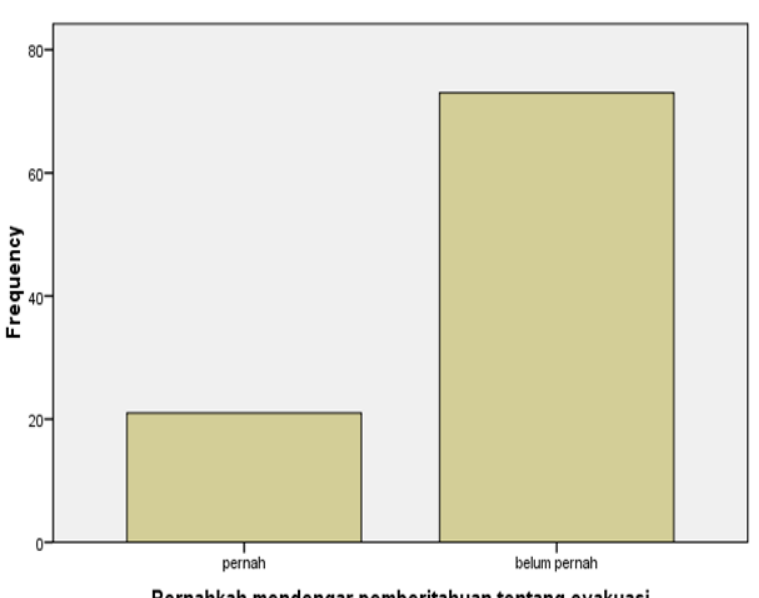

pa yang dilkaukan jika ada perintah pengosongan

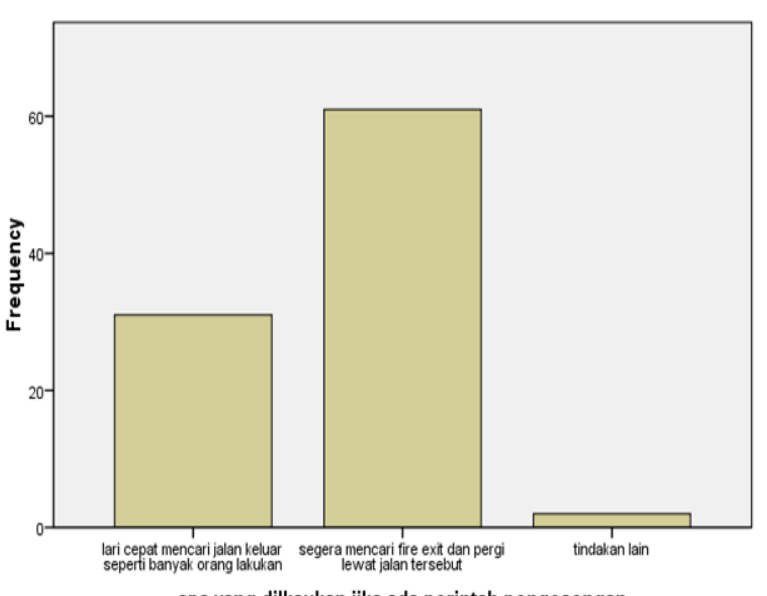

apa yang dilkaukan jika ada perintah pengosongan

Gambar 12. Pemahaman responden terhadap isyarat pemberitahuan tentang evakuasi korban kebakaran (evacuation paging) dan respon mereka terhadap pemberitahuan tersebut.

6. Pemahaman responden dengan betapa berbahayanya asap yang ditimbulkan oleh bencana kebakaran.

Asap merupakan pembunuh nomor satu dari sebab

lain bencana kebakaran. Pengetahuan dan informasi yang benar bagaimana harus bertindak ketika asap mengepul di sebuah lokasi bangunan yang terbakar akan memperkecil resiko jatuhnya korban jiwa. Hasil survey menunjukkan 63\% responden mengetahui betapa mematikannya asap sebuah kebakaran. Akan tetapi hanya 45\% saja dari semua responden yang menjawab dengan benar ke arah mana mereka harus mencari jalan ketika asap mulai bergerak di ruangan mereka sedang berada. Penghuni bangunan bertingkat harus mencari fire exit terdekat ketika asap mulai bergerak dan bukan melewati jalan yang biasa dilalui. Temuan survey ini menunjukkan rendahnya pengetahuan responden tentang hal serius ini.

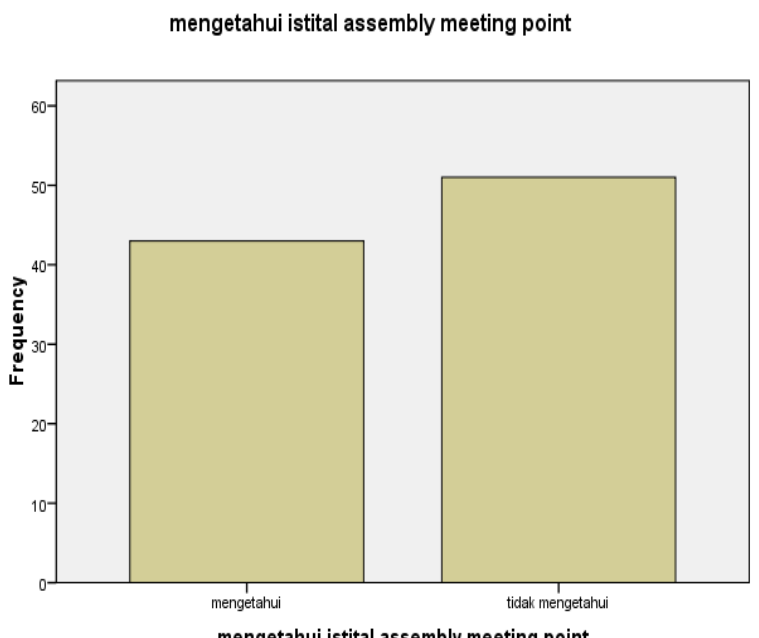

mengetahui lokasi assembly meeting point di UK petr

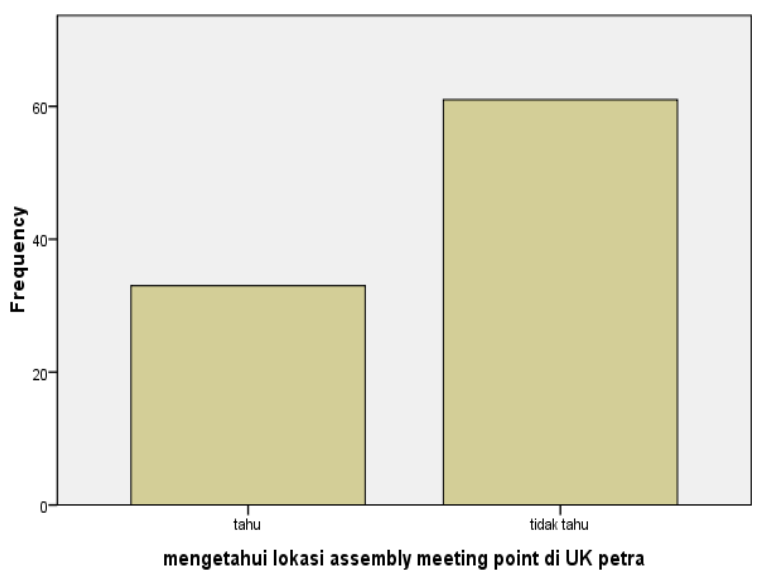

Gambar 13. Pemahaman responden tentang assembly meeting point

7. Pemahaman responden tentang bahaya dari penggunaan lift ketika terjadi kebakaran.

Penggunaan lift untuk lari dari bangunan dilarang ketika terjadi kebakaran. Fungsi lift sebagai pemindah beban dikawatirkan tidak berjalan 
semestinya ketika sebuah kejadian kebakaran terjadi yakni lift akan menutup dan berhenti ketika suplai listrik yang menjadi tenaganya telah mati. Dilain pihak kecenderungan orang panik untuk mencari jalan pintas untuk turun dengan lift akan membuat penumpukkan orang di koridor-koridor penunggu lift, yang tentu saja hal ini kontra produktif dengan upaya evakuasi. Hasil survei menunnjukkan 82\% responden paham dengan dilarangnya penggunaan lift dalam evakuasi kebakaran.

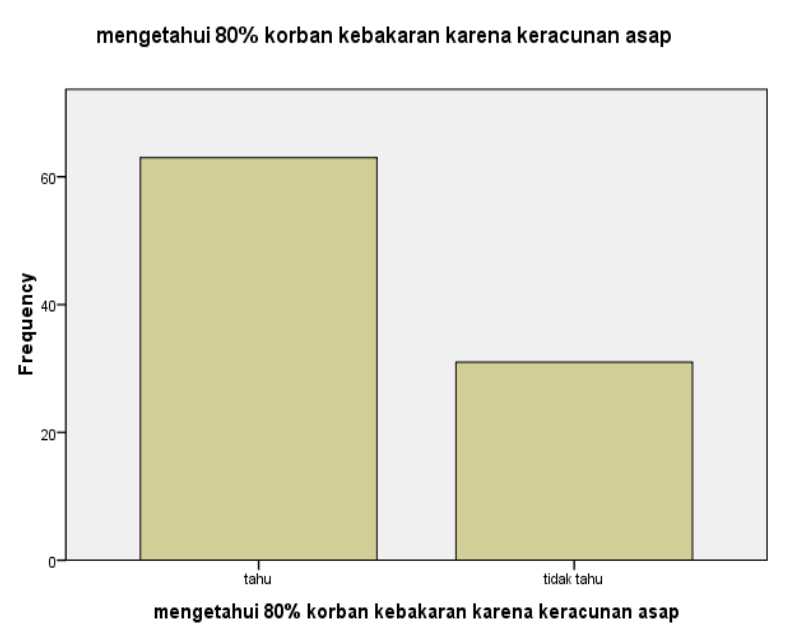

apa yang dilakukan ketika asap menyebar

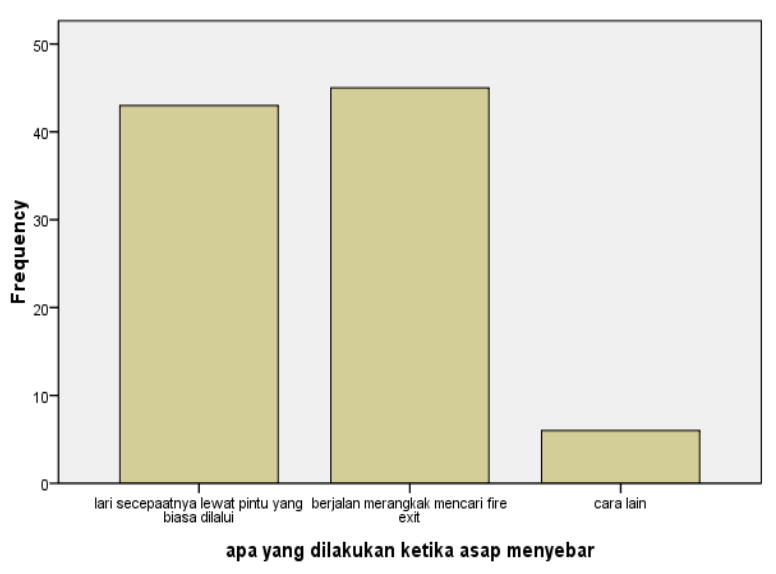

Gambar 14. Pemahaman responden terhadap bahaya Asap

8. Keterkaitan antara informasi tentang bahaya kebakaran serta latihan kebakaran dengan pemahaman para responden akan bahaya kebakaran.

Penulis mendapatkan temuan bahwa sebagian besar responden tidak cukup informasi atau pengetahuan tentang bahaya kebakaran. Hal ini bisa dilihat dari dari indikator-indikator penting untuk mendapatkan informasi dan pengetahuan seperti lewat uji coba kebakaran (fire drill), pelatihan kebakaran (fire training) serta prosedur emergency yang terdapat dalam booklet emergency yang diterbitkan oleh universitas. Lebih dari $60 \%$ responden tidak telah mendapatkan informasi atau pengetahuan lewat tiga cara diatas. Hal ini merupakan temuan yang penting karena dengan keterbatasan informasi dan pengetahuan tentang bahaya kebakaran akan mengarahkan penghuni bangunan bertingkat berkecenderungan tenggelam dalam kepanikan apabila kejadian kebakaran benar-benar terjadi. Hal ini mengindikasikan bahwa pengetahuan tentang bagaimana menghadapi bahaya kebakaran masih cukup rendah di kalangan responden. Rendahnya tingkat pengetahuan ini disebabkan kurang disosialisasikan atau dikomunikasikannya kegiatan atau media yang menginformasikan tentang bahaya kebakarang di gedung bertingkat ini Pengetahuan yang baik untuk menghadapi api yang masih belum menyebar akan meminimalkan kerugian yang lebih besar.

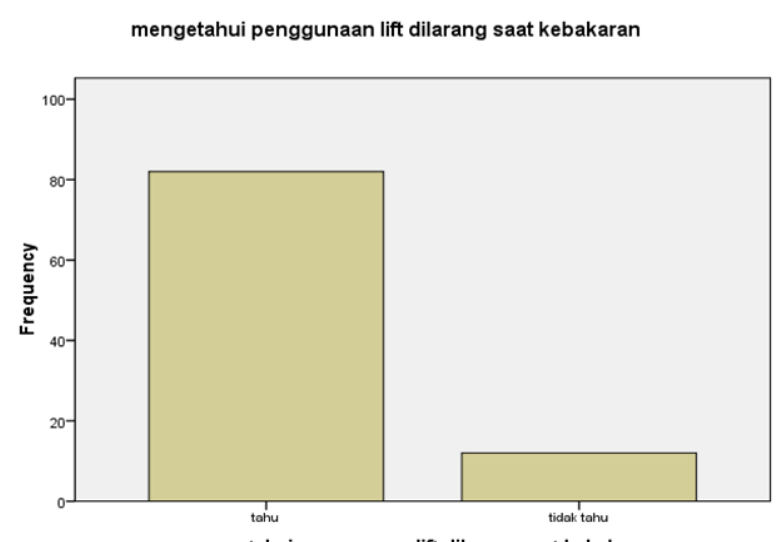

Gambar 15. Pemahaman responden tentang bahaya dari penggunaan lift ketika terjadi kebakaran.

Ditemukan hanya 32\% responden pernah mengikuti pelatihan bahaya kebakaran dan hanya $26 \%$ dari responden yang pernah membaca booklet emergency kampus. Temuan ini menggambarkan masih belum meratanya informasi \& pengetahuan tentang bagaimana menghadapi situasi darurat sebagai akibat bahaya kebakaran. Dari 32\% total responden yang pernah mengikuti pelatihan bahaya kebakaran menyatakan kegiatan itu bermanfaat, hanya seorang responden saja menyatakan kegiatan tersebut tidak bermanfaat. Ini mengindikasikan bahwa kegiatan ini efektif untuk menimbulkan kesadaran. 

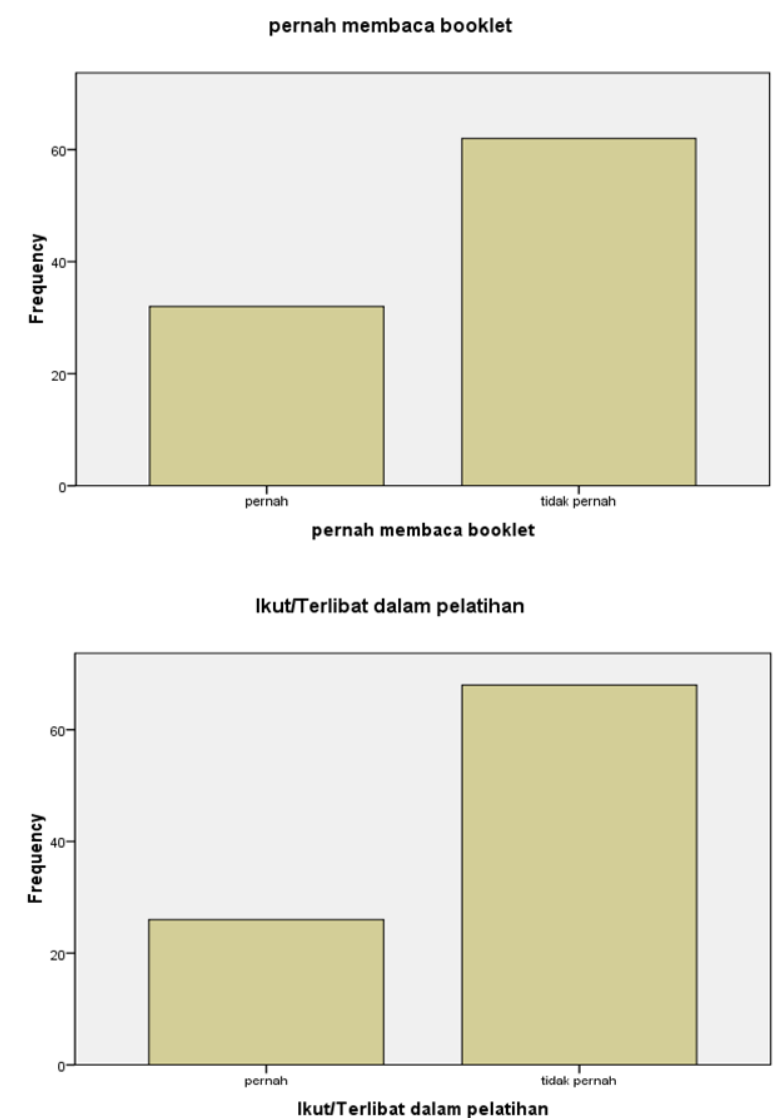

Gambar 16. Keterkaitan antara informasi tentang bahaya kebakaran serta latihan kebakaran dengan pemahaman para responden akan bahaya kebakara

Informasi yang disebarkan lewat booklet emergency ternyata tidak populer dikalangan responden, yakni hanya 26\% menyatakan pernah membaca. Ini artinya penyebaran maupun pengkomunikasian booklet ini belum sampai kepada yang diharapkan. Dari $26 \%$ responden itupun diketahui masih ada seperlima yang tidak paham dengan prosedur menemukan api. Ditemukan juga hampir setengah dari responden yang pernah membaca booklet, tidak paham dengan prosedur evakuasi yang merupakan tingkatan paling berbahaya dari bahaya kebakaran. Semakin sedikit informasi dan pengetahuan tentang menghadapi keadaan emergency akan melipatgandakan resiko yang harus dihadapi dari sebuah kejadian gawat darurat.

9. Menemukan media yang paling direkomendasikan oleh para responden untuk meningkatkan kesadaran tentang bahaya kebakaran ini.

Penulis ingin mengetahui apakah media yang paling efektif di benak para responden dalam meningkatkan kesadaran para penghuni gedung bertingkat yang ada di UK petra berkenaan dengan bahaya kebakaran. Media yang teraplikasikan dengan baik akan meningkatkan kesadaran yang pada giliranya akan merubah perilaku. Ada empat media yang bisa digunakan untuk semakin meningkatkan kesadaran,yakni diadakannya fire training, fire drill, pemasangan booklet emergency ditempat-tempat strategis dan pembuatan booklet pribadi yang berisi tentang prosedur kebakaran. Hasil survey menunjukkan bahwa 34\% responden menginginkan agar tidak hanya satu media saja tapi harus ada lebih dari satu media yang harus disosialisasikan agar kesadaran tentang bahaya kebakaran meningkat. Sementara 27\% responden juga memilih Latihan Kebakaran (fire Drill) sebagai media yang dipilih. Ini artinya bahwa pihak Universitas harus memfasilitasi agar Fire Drill diadakan secara reguler. Fire drill biasanya berjenjang dari tanpa evakuasi, partial evacuation sampai kepada total evacuation. merupakan latihan kebakaran yang memerlukan waktu, tenaga dan pikiran karena menghendaki semua Berikut data statistic tentang media yang dipilih oleh responden:

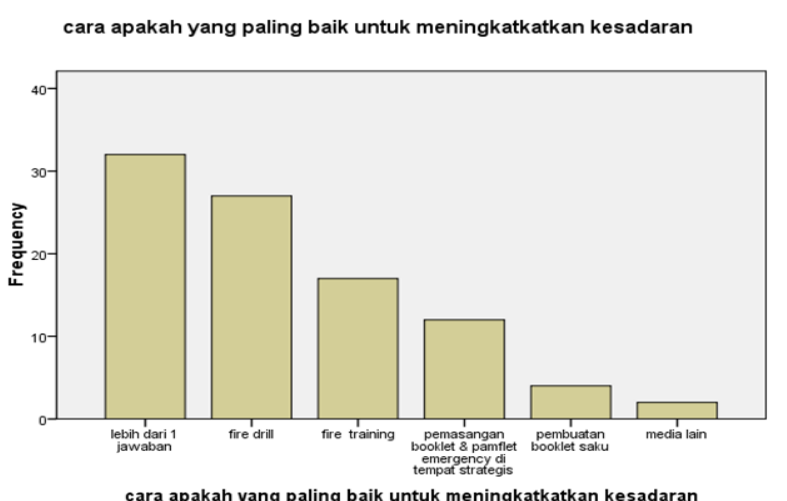

Gambar 17. Media yang paling direkomendasikan oleh para responden untuk meningkatkan kesadaran tentang bahaya kebakaran

\section{KESIMPULAN DAN REKOMENDASI}

\section{Kesimpulan}

Dari hasil survey, penulis mengambil beberapa kesimpulan berkenaan dengan kesadaran penghuni gedung bertingkat yang ada di lingkungan Universitas Kristen Petra: Dengan pertimbangan bahwa bahaya kebakaran sangat erat hubungannya dengan fatal risk atau resiko yang sangat fatal, penulis berasumsi bahwa tingkat kesadaran harus tinggi dan merata di antara para penghuninya, yakni didapatnya nilai yang maksimal dan merata diantara para responden: 
1. Dari hasil survei didapatkan bahwa kesadaran responden tentang bahaya kebakaran masih rendah dengan ditunjukkan oleh presentase yang masih jauh dari nilai maksimalnya serta ditunjukkan dengan belum meratanya distribusi kesadaran dari semua responden. Hal ini mengindikasikan bahwa kesadaran diantara penghuni bangunan masih rendah artinya para penghuni gedung bertingkat yang ada di lingkungan UK Petra belum sepenuhnya menyadari apa yang harus mereka lakukan ketika terjadi kebakaran. Penulis beranggapan bahwa rendahnya kesadaran lebih disebabkan oleh belum tersosialisasi dan terkomunikasikannya media maupun kegiatan untuk memberitahukan akan bahaya kebakaran dan bagaimana mengantisipasi serta menghadapi ancaman tersebut.

2. Ada keterkaitan yang erat antara program pelatihan menghadapi kebakaran yang meliputi fire drill, fire training dengan timbulnya kesadaran. Dari hasil survey terlihat bahwa para responden sebenarnya telah memiliki kesadaran akan bahaya dan resiko kebakaran yakni dari media atau sumber yang mereka baca atau dengar, hanya yang jadi masalah adalah mereka belum terkomunikasikan bagaimana informasi atau pengetahuan untuk menghadapi dan mengantisipasi bahaya tersebut, sehingga kesadaran tersebut belum merubah sikap dan perilaku.

\section{Rekomendasi}

Penulis merekomendasikan dua langkah perencanaan untuk meningkatkan kesadaran akan bahaya kebakaran , yakni:

1. Pengkomunikasian informasi tentang prosedur gawat darurat (emergency) secara massal untuk semua sivitas akademika UK Petra. Kegiatan bisa dirupakan dengan kuliah tambahan bersubyek "Safety Briefing" untuk para mahasiswa di awal semester dan kegiatan yang sama untuk para staff yang bisa dirupakan internal training di awal semester. Isi kegiatan tidak hanya tentang bahaya kebakaran saja akan tetapi juga prosedur darurat untuk jenis ancaman dan bahaya yang lain.

2. Melaksanakan secara periodik fire drill dan evacuation drill secara parsial maupun massal. Istilah periodik bisa diartikan tiap enam bulan sekali, sementara parsial artinya di sub gedung (satu atau dua lantai) dan massal bisa diartikan semua lantai yang ada di gedung tersebut. Skenario latihan harus dibuat sedemikian rupa sehingga bisa menumbuhkan sikap (sense of crisis) dan merubah perilaku para penghuni.

Perlu disadari bahwa resiko kebakaran akan terjadi dimanapun juga seseorang berada baik di rumah maupun gedung bertingkat. Dan ketika orang telah memiliki kesadaran tinggi maka seseorang setidaknya akan tidak panik menghadapi bahaya kebakaran dan terlebih lagi dia akan responsif terhadap resiko yang mungkin terjadi.

\section{DAFTAR PUSTAKA}

Fatma Lestari, Yodan Amaral Panindrus RM. (2008), Jurnal Audit Sarana Prasarana Pencegahan Penanggulangan dan Tanggap Darura Kebakaral di Gedung Fakultas X Universitas Indonesia Tahun 2006, Makara Teknologi Volume 12 No 1 Tahun 2008

Nawal Bt Hj Mohd Khuzairi (2007), Tesis Sikap dan Tindak Balas Penghuni Bangunan dalam Menghadapi Situasi Kebakaran Kajian Kes Menara Anshar Johor Baru, Universiti Teknologi Malaysia

Sunarno (2009), Artikel Anjung Nusa Edisi No 014/Des - 2009

Suprapto (2008), Jurnal Tinjauan Eksistensi standarstandar (SNI) Proteksi kebakaran dan Penerapannya dalam mendukung Implementasi Peraturan Keselamatan Bangunan, Prosiding PPIS Bandung

(2007), Journal Learning Theory by MJu from training of instructors/teachers in more than 40 countries between 1965-2007, FAO/CBFiM workshop programme by Firmit Consulting

(1986), Journal Fire \& Smoke; Understanding the Hazards, National Academy of Science.

(2007), Journal Rethinking the High Rise Elevator, The American Society of Mechanica Engineering.

(2008), Journal Exposing an Invisible Killer; The Dangers of Carbon Monoxide Study: Unintentional Non-Fire-Related Carbon Monoxide Exposures, US Fire Administration 